\title{
ВИКОРИСТАННЯ ТВОРІВ СУЧАСНИХ УКРАЇНСЬКИХ КОМПОЗИТОРІВ ДЛЯ ДІТЕЙ І ЮНАЦТВА У ФОРТЕПІАННІЙ ПІДГОТОВЦ МАЙБУТНІХ МУЗИКАНТІВ-ПЕДАГОГІВ
}

2. Hrishnova, O.A. (2001). Liudskyi kapital: formuvannia $\mathrm{v}$ systemi osvity i profesiynoi pidhotovky [Human capital: formation in the system of education and professional training]. Kyiv, 254 p. [in Ukrainian].

3. Bekh, Yu.V. (2014). Intelektualnyi kapital orhanizatsiyi: strukturno-funktsionalnyi pidkhid [Intellectual capital of an organization: structural and functional approach]. Politology Bulletin. 2014. Vol. 74. pp. 86 -97. [in Ukrainian].

4. Hrishnova, O.A. (2011). Nahromadzhennia liudskoho, intelektualnoho i sotsialnoho kapitalu pidpryemstva yak osnovna forma yoho kapitalizatsii [Accumulation of human, intellectual and social capital of the enterprise as the main form of its capitalization]. Bulletin of the Donetsk University of Economy and Law. No. 1. pp. 10-13. [in Ukrainian].

5. Ivanilov, O.S. (2009). Ekonomika pidpryemstva [Economy of an Enterprise]. Kyiv, 728 p. [in Ukrainian].
6. Zavadskyi, Y.S., Osovska, T.V.\& Yushkevych, O.O. Ekonomichnyi slovnyk [Economic Dictionary]. Kyiv. 2006. p. 355. Available at: http://library.nlu.edu.ua/POLN TEXT/ KNIGI/KONDOR/EKONOMIC SL 2006.pdf [in Ukrainian].

7. Slovar sovremennoy ekonomicheskoy teorii (1997). [Dictionaty of contemporary economic theory]. (Ed.). A.H. Pivovarov. Moscov, 608 p. [in Russian].

8. Kharchuk, T.V. (2005). Upravlinnia rozvytkom liudskoho kapitalu v orhanizatsiakh systemy vyshchoi osvity [Managenemt of the development of human capital in institutions of higher education]. Candidate's thesis. Kyiv, 184 p. [in Ukrainian].

9. Shulha, Zh.O. (2010). Intelektualnyi kapital yak obyektyvna ekonomichna katehoria [The intellectual capital as an objective economic category]. Bulletin of Berdyansk University of Management and Business. No. 2(10).pp. 106-111.

Стаття надійшла до редакції 16.09.2020

УДК 378:37.011.3-051:780.616.432:781.5-053.5/6

DOI:

Ірина Новосядла, кандидат мистеитвознавства, дочент кафедри методики музичного виховання та диригування ДВНЗ “Прикарпатський національний університет імені Василя Стефаника"

\section{ВИКОРИСТАННЯ ТВОРІВ СУЧАСНИХ УКРАЇНСЬКИХ КОМПОЗИТОРІВ ДЛЯ ДІТЕЙ І ЮНАЦТВА У ФОРТЕПІАННІЙ ПІДГОТОВЦІ МАЙБУТНІХ МУЗИКАНТІВ-ПЕДАГОГІВ}

У статті актуалізовано питання оновлення репертуару студентів з предмету "Профільний інструмент фортепіано”. Розглянуто художні особливості композицій сучасних авторів, проаналізовано вибрані п'єси як приклади втілення образного змісту засобами модернової композиторської мови; охарактеризовано їх стильові риси. Зазначено, що вивчення творів різних жанрів і стилів сприяє розширенню світогляду студентів, збагаченню їх уявлень про сучасну украӥнську музику, ознайомленню з творчістю маловідомих композиторів, а також розвитку піаністичних навичок і творчого мислення.

Ключові слова: сучасна украӥнська фортепіанна музика для дітей і юнацтва; заклад вищої освіти; навчання гри на фортепіано; дидактичний репертуар; музично-педагогічна діяльність; розвиток творчого мислення.

Jim. 8.

Iryna Novosyadla, Ph.D.(Art Science), Associate Professor of the Music Education and Conducting Methods Department, Vasyl Stefanyk Precarpathian National University

\section{ON USING CONTEMPORARY UKRAINIAN COMPOSERS' WORKS FOR CHILDREN AND YOUTH IN PIANO TRAINING OF FUTURE MUSICIANS AND EDUCATORS}

The article defines the contemporary priorities of choosing the teaching material for training the musician and educator. On the one hand, the material must meet the key requirements of the national education and upbringing, and, on the other hand, it must bring the requirements of the globalized community into conformity with its cultural artistic integration processes. The article deals with the issue of enriching the repertoire of the students of speciality 014. Secondary Education (Musical Art) on the subject "Piano as the Major Instrument" with the works for children and youth created by contemporary Ukrainian composers. During the last decades, a number of multi-genre interesting compositions for the piano have been included into Ukrainian teaching literature. They have been created by such professional composers, teachers-pianists and concert Jazz performers as S. Sukhoshcheyeva, Ia. Bobalik, L. Pratsyuk, E. Brylin, K. Maydenberg-Todorova, N. Lahodyuk, O. Saratskiy and others. Taking into consideration the tastes of the contemporary younger generation, authors actively turn to various types of jazz music, use modern music related vocabulary, resort to tone painting and special timber effects. The present research 
has considered the artistic peculiarities of compositions, whose studying can be useful for the future musical and pedagogical activity of students. There have been analyzed compositions by N. Lahodyuk, O. Lychkina, V. Manyk, A. Boyko, O. Nezhyhay, $V$. Telychko as examples of manifestation of figurative content by means of the contemporary composers' language. The stylistic and compositional peculiarities of the selected pieces of music have been characterized. There has been highlighted the essential didactic role of contemporary Ukrainian composers' works in teaching piano playing to future musicians and educators. It has been emphasized that learning compositions of various genres and styles contributes to broadening the students' outlook, enriching their knowledge of contemporary Ukrainian music, acquainting them with the creative activity of little-known composers, and developing piano playing skills.

Keywords: contemporary Ukrainian piano music for children and youth; higher education institution; piano playing learning; the didactic repertoire; musical and pedagogical activity; developing of creative thinking.

П остановка проблеми. Сучасні орієнтири у підготовці культурноосвіченого музиканта-педагога зумовлюють відповідні пріоритети у виборі навчального матеріалу, який повинен, 3 одного боку, відповідати ключовим вимогам національнопатріотичного виховання, а 3 іншого - бути суголосним запитам глобалізованого суспільства 3 його культурно-мистецькими інтеграційними процесами. У цьому сенсі фортепіанне навчання володіє значним потенціалом для формування як національної свідомості, так і розширення світогляду студентів, розвитку їх художнього мислення, розкриття індивідуальних творчих можливостей. Крім того, процес навчання 3 предмету "Профільний інструмент фортепіано" передбачає ефективне використання міждисциплінарних зв'язків, що позитивно впливає на розвиток професійних якостей студентів музичнопедагогічних факультетів.

Сьогодні склалася ситуація, коли до закладів вищої освіти на спеціальність 014. “Середня освіта (Музичне мистецтво)" вступає молодь 3 різним рівнем музичної підготовки, часом, не маючи початкової музичної освіти. Ці обставини зумовлюють потребу у внесенні змін до навчальних програм у класі фортепіано, зокрема, в оновленні репертуару студентів, який, крім обов'язкового вивчення класичних творів, повинен враховувати смаки теперішнього покоління, сприяти прищепленню любові до рідної музики і водночас знайомити з модерновими тенденціями музичного мистецтва. 3 огляду на це сприятливим і ефективним матеріалом для формування і розвитку практичних умінь студентів, а також збагачення їх теоретичних знань є сучасна українська фортепіанна музика для дітей і юнацтва, представлена композиціями різних жанрів і стилів. За останні десятиріччя виразно проявилась тенденція, коли до поповнення педагогічного репертуару долучаються музиканти, котрі поєднують викладацьку i композиторську діяльність, працюючи у музичних закладах освіти різних ступенів (С. Острова, Е. Брилін, Л. Працюк, Н. Лагодюк, Г. Без'язичний,
О. Нежигай, Я. Бобалік, Л. Волошина, О. Личкіна та ін.). Можна провести аналогії з 20-30-ми роками минулого століття, коли українські митці - композитори, піаністи-педагоги, фундатори професійної музичної освіти (С. Людкевич, В. Барвінський, М. Колесса та ін.) - відчуваючи гостру потребу у педагогічному репертуарі, зверталися до написання дитячої музики. Сьогодні це $є$ абсолютно закономірним, оскільки, по-перше, створюючи свої опуси, автори враховують уподобання і виконавські можливості юних піаністів, а, подруге, новий час кидає інші виклики: сучасне підростаюче покоління прагне новизни у музичній мові, образному змісті. Вивчення цих творів у процесі фортепіанної підготовки майбутніх музикантів-педагогів допоможе розв'язати кілька завдань одночасно: поповнити їх уявлення про сучасну українську музику, ознайомити 3 творчістю маловідомих композиторів, розвинути піаністичні навички. Знайомство студентів 3 музичними творами, що відображають різнобарвний світ дитинства, викликають відповідні емоції і залишають яскраві враження, стане корисним для збагачення їхньої ерудиції і застосування у майбутній музично-практичній діяльності - педагога-піаніста в дитячій музичній школі, музичного керівника в закладі дошкільної освіти чи викладача музичного мистецтва в загальноосвітній школі.

Аналіз останніх досліджень і публікацій. Упродовж останніх десятиліть такий значний пласт української музики, як фортепіанна література для дітей, привертає до себе увагу музикознавців. Якщо порівнювати кількість статей, монографій чи посібників, написаних до 90-х p. ХХ ст., з науковими дослідженнями від початку періоду незалежності, сьогодні бачимо суттєве зростання інтересу. Зокрема, естетикопсихологічні засади фортепіанної творчості для дітей українських піаністів-педагогів XX ст. розглядаються у дисертації 3. Юзюк; дослідженню фортепіанних циклів українських композиторів для дітей присвячені праці О. Тимощук, О. Фрайт; виховні можливості сучасної української музики, написаної для юних піаністів, 


\section{ВИКОРИСТАННЯ ТВОРІВ СУЧАСНИХ УКРӒ̈НСЬКИХ КОМПОЗИТОРІВ ДЛЯ ДІТЕЙ І ЮНАЦТВА У ФОРТЕПІАННЙ ПДГОТОВЦІ МАЙБУТНІХ МУЗИКАНТІВ-ПЕДАГОГІВ}

сталипредметом наукових публікацій Н. Мозгальової, С. Глушкової. Л. Данілішиної, К. Гаран та ін. Сучасні тенденції формування українського фортепіанного педагогічного репертуару висвітлено автором пропонованої статті у дисертації і низці публікацій. Але якщо українська дитяча фортепіанна музика XX ст. висвітлена грунтовніше, сучасний педагогічний репертуар, котрий від початку XXI ст. стрімко розвивається, інспірує до нових наукових розвідок. Також зауважимо, що результати експериментального дослідження 3. Ластовецької-Соланської щодо музичних пріоритетів у системі ціннісних орієнтацій молоді свідчать про значне зниження інтересу до класичної музики, її витіснення пластом розважальної музики. Авторка піднімає питання необхідності переоцінки завдань сучасної музичної освіти, в якій основний акцент слід перенести з демонстраційної, концертно-показової спрямованості художньо-виховної практики на стратегії культуротворчості, формування національної свідомості української молоді, розвиток їі художньо-естетичної культури.

Тому, метою статті $\epsilon$ обгрунтувати національно-виховний, пізнавальний і дидактичний потенціал фортепіанних творів сучасних українських композиторів початку XXI ст. у формуванні фахових навичок майбутніх музикантів-педагогів. У статті використано власний досвід викладання дисципліни “Профільний інструмент фортепіано” в роботі зі студентами Прикарпатського національного університету ім. В. Стефаника.

Виклад основного матеріалу. Твори для дітей і юнацтва посідають вагоме місце у величезній за обсягом українській фортепіанній музиці. Понад століття композитори проявляли інтерес до цієї ділянки творчості, з великою відповідальністю ставлячись до своєї праці, адже усвідомлювали важливість впливу музичних творів на формування естетичних смаків юних музикантів, збагачення їх світогляду та розвиток піаністичних умінь.

Від початку 90-х р., із проголошенням незалежності нашої держави, почався процес національного відродження, котрий вплинув на розвиток культури: зріс попит на український продукт, українську музику [8]. Це спричинило появу великої кількості різножанрових творів вітчизняних композиторів - як академічної, так і популярної музики. У перше десятиліття XXI століття цей процес став ще інтенсивнішим. Поява величезної кількості різноманітних конкурсів і фестивалів дитячої виконавської майстерності посприяла зростанню інтересу до сучасної української музики, тож, відповідно, значний попит не міг не викликати відповідні пропозиції. До написання нових творів, крім композиторів старшого покоління, долучились молоді митці - переможці конкурсів композиторської творчості, педагоги-піаністи. Для декого написання фортепіанних опусів стало підсумком педагогічного досвіду і результатом наукових пошуків [1]. Музика сучасних українських авторів, оновлена сьогоденним сприйняттям дітей та молоді, новітніми досягненнями в засобах музичної виразності, спрямованими на вирішення оригінальних образних задумів, презентує цікаві творчі знахідки.

Найпоширенішим в українській фортепіанній музиці для дітей $є$ жанр мініатюри: програмноїяка детермінує образно-асоціативний напрям сприйняття, і непрограмної, традиційна ознака якої - використання народних пісенно-танцювальних джерел чи жанрово-стильових особливостей західноєвропейської музики [4]. Композитори об'єднують мініатюри у поліжанрових збірках як, наприклад, “Дитячий альбом” (I. Щербакова, О. Личкіної, С. Острової, В. Теличка), "Мозаїка" Г. Саська, "Музичний дивосвіт” Л. Волошиної, "Музичне сузір'я” Я. Бобалік, “Дитяча мозаїка" М. Ластовецького, “Ліричний зошит” Л. Сухощєєвої, “Фортепіанні п'єси для дітей та юнацтва" В. Маника, “Юному віртуозу” Е. Бриліна, “Джазові хвилинки” Н. Лагодюк, “Магія фортепіано” Ю. Білковського тощо; у сюїтах (“Мої іграшки”, “Цирк” Л. Шукайло, “Андрійкові забавки” О. Костіна, “Дитяча сюїта”, “Портрети”, “Навколосвітня подорож” В. Маника, “Граю джаз” Г. Саська, “Будні юного музиканта або життя, як воно є” О. Нежигая, “Старовинні танці” О. Яковчука та ін.); а також у моножанрових циклах (“Українські ноктюрни” Г. Мартиненко, цикли прелюдій “Пори року” В. Маника, “Осінні акварелі” О. Герасименко, “Характерні п’єси у формі етюдів” Г. Без'язичного і т.п.).

Сьогодні ідеї вітчизняної освіти актуалізують використання національних культурних надбань, зокрема українських традицій та музичного фольклору, перетворюючи їх на пріоритетні засоби виховання дітей та молоді. Тож міцні спадкоємні зв’язки поколінь композиторів відслідковуються у шанобливому ставленні до рідних витоків. Український фольклор активно використовується в авторських обробках, які пронизані інтонаціями народної пісні та ритмічним колоритом танцювальної музики. Для національної музичної мови характерна етнічна манера інтонування, котра у професійній музиці “переплавляється" 


\section{ВИКОРИСТАННЯ ТВОРІВ СУЧАСНИХ УКРАЇНСЫКИХ КОМПОЗИТОРІВ ДЛЯ ДІТЕЙ І ЮНАЦТВА У ФОРТЕПАННІЙ ПІДГОТОВЦ МАЙБУТНІХ МУЗИКАНТІВ-ПЕДАГОГІВ}

крізь призму стилю композитора [3]. Звертаючись до першоджерела, сучасні митці, сміливіше, порівняно $з$ попередниками, підходять до його опрацювання: не обмежуючись простою гармонізацією мелодії, вони видозмінюють іiі, використовуючи багаті колористичні можливості інструмента, цікавий ритмічний малюнок тощо. Серед таких прикладів - “Дощик, дощик”, “Ягілочка” Л. Сухощєєвої, “Ой, на горі калина” А. Потапова, “Ой, Марічко, чичері”, “Я в середу родилася”, “Ой, кіт воркне” А. Бойко, “Несе Галя воду” Е. Бриліна, цикл ноктюрнів Г. Мартиненко, композиції М. Ластовецького ("Бойківські образки”, цикли “Веснянки”, “Колискові”, “Два танці”, сюїта "Мелодії бойківського весілля”), збірки "Наші веснянки", “Наші колядки" Р. Никифоріва. Репрезентуючи багату жанрову палітру української музичної традиції в найпопулярніших жанрах - лірична, жартівлива, колискова, обрядова пісня (колядка, веснянка, гаївка, весільна), танець, марш, - в інтонаційнообразних перевтіленнях основних тем композитори поєднують характерні стильові властивості народної музики з сучасними виразовими прийомами фактури, гармонії, поліфонії: використовують елементи довільної імітації, атоналізму, дисонансні альтернативні акорди, кластери та інші модернові засоби виразності; широко застосовують звуконаслідування народного інструментального музикування - гри на бандурі, скрипці, цимбалах, сопілці, трембіті, дримбі тощо, а також традиції пісенно-хорового мистецтва. Так, наприклад, із художньою стилізацією архаїчного жанру - веснянки студенти можуть познайомитись на прикладі “Веснянки” 3 “Дитячої сюїти” В. Маника та “Веснянки” № 4 М. Ластовецького. В основі змісту обох п'єс - обряд зустрічі весни, спільними 3 народною музикою є ладова палітра, ритмоінтонаційний рисунок, прийоми розвитку, проте кожен митець демонструє власне бачення образного змісту, використовуючи сучасну музичну мову. Мелодія п'єси В. Маника будується на повторюваності мотивів-поспівокперегуків закликів-прохань до природи, до Весникрасни. Витриманий бас і наступні акорди в акомпанементі створюють ефект церковних дзвонів. У “Веснянці” М. Ластовецького більш виражена інтеграційна синкретична природа жанру, його язичнецькі корені. На думку дослідниці творчості композитора О. Фрайт, М. Ластовецький трактує цю п’єсу “...як нероздільне ритуальне дійство, що увібрало в себе магію пісні, танцю й обряду" [7, 79].

Серед фольклорних жанрових танцювальних різновидів традиційно увагу митців привертає коломийка (“Коломийка” М. Ластовецького, В. Теличка, “Навесні” Л. Працюк, “Буковинський візерунок” Н. Лагодюк тощо). У п’єсі “КоломийкаРоксолана" І. Тараненка елементи гуцульського фольклору (характерні “коломийкові” поспівки, ладове забарвлення, своєрідна ритмічна пульсація) поєднуються 3 виразовими засобами сучасної естрадної музики (свінговий ритм, поліритмія, різкі акценти, синкопи).

Оригінальне перевтілення фольклорного матеріалу демонструють варіації на теми українських народних пісень: “Вийди, вийди, Іванку”, “Налетіли журавлі”, “Було літо”, “Ой, чий то кінь стоїть" А. Бойко, "Ніч яка місячна" Г. Мартиненко, “Цвіте терен” С. Острової, “Ой, на горі калина” В. Маника та ін..). Зокрема, неоромантичною стилістикою вирізняються варіації на тему “Ой, чий то кінь стоїть” А. Бойко. Лірична пісенність основної теми змінюється бравурною вальсовістю у першій варіації, енергійною експресією - в другій, “мерехтінням” тріольних візерунків - у третій, нестримною емоційністю - у четвертій і драматичною напругою - у коді. Розвинений віртуозний стиль варіацій А. Бойко, що виражений стрибками, гамоподібними пасажами, стрімкими злетами у швидкому темпі, широким регістровим охопленням, філігранною орнаментикою, сягає корінням в романтичний піанізм західноєвропейських композиторів XIX ст. Водночас, вдаючись до експериментів в опорі на фольклорну мелодику, композиторка майстерно поєднує елементи народного інструментального музикування, колоритні модуляції, альтерації, імпровізаційність. В основі джазових “Варіацій на тему української народної пісні” Н. Лагодюк - жартівлива пісня “Ти до мене, ти до мене не ходи": мелодійна, динамічно гнучка тема набуває нових обрисів за рахунок зміни фактури та ритмічної імпровізаційності (з елементами свінгу, бугі-вугі та регтайму).

Зауважимо, що джазові обробки фольклорних мелодій сьогодні $є$ надзвичайно популярними. Різновиди джазу послугували інтонаційноладовою та ритмічною основою для імпровізацій на теми українських народних пісень у творах Н. Лагодюк, О. Саратського, О. Нежигая. Так, цікавий приклад трансформації відомої української народної пісні “По садочку ходжу” демонструє п’єса “Мрійливий настрій” Н. Лагодюк, в якій журливий, ліричний образ першоджерела набуває цілком інших обрисів. Імпровізаційна манера викладу тематичного матеріалу, нарочита безтурботність відповідають закладеній у назві 


\section{ВИКОРИСТАННЯ ТВОРІВ СУЧАСНИХУКРАЇНСЬКИХ КОМПОЗИТОРІВ ДЛЯ ДІТЕЙ І ЮНАЦТВА У ФОРТЕПІАННІЙ ПІДГОТОВЦІ МАЙБУТНІХ МУЗИКАНТІВ-ПЕДАГОГІВ}

програмі твору. У п’єсі “'Ой, коте, коточку” О. Нежигая інтонації відомої колискової “Котику сіренький” поєднуються з ритмікою і ладово-гармонічними особливостями блюзу. Великою популярністю у студентів користуютьсяджазові обробкиО. Саратського - “Чорнії брови, карії очі”, “Коломийка”, “Ой, у вишневому саду” та ін., в яких автор поєднав фольклор, джаз та академічну музику.

У сучасній українській фортепіанній літературі широко представлена тематика, пов'язана зі світом дитячих забав, іграшок, захоплень, образами улюблених тваринок [2]. Залучення до репертуару студентів таких мініатюр, як “Ляльковий театр” Е. Бриліна, “Ляльки танцюють” Л. Шукайло, “Клоуни в інших, може бути багатофункціональним. Їх можна використовувати як для розвивального навчання (нескладна фактура п'єс, прості піаністичні завдання сприяють удосконаленню навичок читки з листа), так і в майбутній практичній діяльності студентів - в дошкільному закладі чи на уроках музичного мистецтва $з$ молодшими школярами. Гра - один із засобів пізнання дитиною навколишньої дійсності, і присутній у мініатюрах елемент гри 3 цікавістю і захопленням сприймається дітьми [5]. Особливо, коли йдеться про п'єси, в яких яскрава образність досягається звукозображальними засобами: наприклад, у п'єсі “Поні” Л. Шукайло “цокання” копит маленької конячки, що їздить по колу, передається постукуванням олівцем по дереву, а одночасне 3 мелодією відбиття ритму ногою і постукування руками по корпусу фортепіано створюють ефект “передражнювання” в "Папузі” О. Костіна.

Оригінальною музичною лексикою i багатством звукопису вирізняються твори, об'єднані тематикою подорожей: 12 мініатюр 3 циклу “Навколосвітня подорож”, тв. 87 В. Маника, ансамблеві п'єси 3 “Дитячого альбому” В. Теличка, “Подорож країнами Свропи” Л.Волошиної. Кожна композиція семантично пов'язана зі звуковими образами музичної культури різних народів. Яскравий колорит створюється за допомогою використання характерної для фольклору тієї чи іншої країни мелодики та ритмічного малюнка, ладових особливостей чи наслідування звучання народних інструментів. Так, характерні мелодичні інтонації перуанської флейти чуємо в тематизмі п’єси “Вітер з гір” (Перу), гітарні награвання “фламенко” - "Про що співає гітара” (Іспанія) з циклу В. Маника; тридольний танцювальний ритм та інтонації австрійського йодлю змальовують в уяві слухача квітучі галявини Альп в мініатюрі “Про Австрію” В. Теличка, а у викладі мелодії в пентатоніці на основі використання чорних клавіш вгадується особливий колорит Країни Сонця, що Сходить (“Про Японію” цього ж композитора). Вивчення п’єс сприяє опануванню різних видів фактури, ритмічного малюнка, тембральних особливостей, а також розширить як власний світогляд студентів, так і їх майбутніх вихованців, збагативши останніх новими звуковими враженнями. П'єси з “Дитячого альбому” В. Теличка для виконання у чотири i шість рук $є$ цікавою знахідкою для ансамблевого репертуару студентів. Крім того, використання мініатюр на тему подорожей у музичній грівікторині допоможе розвинути образноасоціативне мислення.

Яскраві асоціації пробуджують також твори, в яких композитори застосовують майстерність звукопису. Фортепіанна ілюстративність супроводжує різні образи: відтворення голосів природи у п’єсах “Бурхливий водоспад” Я. Бобалік, “Елегія моря” А. Бойко, “Лісовий оркестр”Е. Бриліна, звуконаслідування в таких мініатюрах як "Надокучлива муха", "Годинник показує ніч" В. Птушкіна, “Комарине полювання”'К. МайденбергТодорової, “Музична скринька” Е. Бриліна та ін.

Емоційний відгук у студентів знаходять ліричні композиції сучасних авторів - елегійно-мрійливі “3 думкою про пісню” Н. Лагодюк, “Мелодія" О. Нежигая, “Ліричний настрій” К. МайденбергТодорової, "Роздуми” Ю. Білковського, чуттєві “Самотній птах”, “Камертон душі” Я. Бобалік та ін. Також різні відтінки ліричного настрою передають непрограмні композиції, написані у жанрах романтичної музики (елегія, поема, прелюдія, ноктюрн, баркарола, інтермецо). Поетична образність характерна для “Елегї”, “Маленької поеми” і “Ноктюрна” Л. Сухощеєвої, “Інтермецо” Л. Шукайло, Е. Бриліна, “Баркароли” Л. Працюк, “Ноктюрна” Н. Лагодюк, Е. Бриліна. Контрастні настрої - від медитативної споглядальності до відкритої емоційності панують у циклі прелюдій "Осінні акварелі" О. Герасименко: тяжіння автора до картинності визначає задум композицій, де розвиток матеріалу $є$ мозаїчним, а образна концепція полягає у втіленні "пасторальних" відтінків настрою. Вивчення п’єс є ефективним для розвитку творчої уяви, кантиленної техніки, оскільки вимагає гнучкого фразування, відповідного туше, майстерності педалізації тощо.

Споглядальна лірика представлена в п'єсах “Ранкове місто” К. Майденберг-Тодорової, “Осінь у моєму місті" Я. Бобалік, "Фарби осені" Л. Волошиної, “Біля озера”, “Осінній пейзаж” Н. Лагодюк, “В степу” Е. Бриліна та багато ін. Щоб відобразити картини мальовничої природи 


\section{ВИКОРИСТАННЯ ТВОРІВ СУЧАСНИХ УКРӒ̈НСЬКИХ КОМПОЗИТОРІВ ДЛЯ ДІТЕЙ І ЮНАЦТВА У ФОРТЕПІАННІЙПІДГОТОВЦІ МАЙБУТНІХ МУЗИКАНТІВ-ПЕДАГОГІВ}

у різні пори року, які калейдоскопічно змінюють одна одну, композитори звертаються до різних жанрів-ноктюрнууциклі “Порироку” Г.Мартиненко (“Весняні потоки”, "Купальська ніч”, “Осіння пісня" та "Різдвяна заметіль"), прелюдії-у циклі "Пори року” В. Маника ("Веснянка", “Літній вітерець”, “Пожовкле листя” та “Зимовий шлях”) та О. Герасименко (“Зимова казка”, “Подих весни”, “Сонячні зайчики”). Зразками використання сонорних ефектів є п’єси В. Маника іК. Майденберг-Тодорової. Автори експериментують 3 фактурою, збагачуючи звучання оригінальними педальними i регістровими знахідками, колористичні ефекти проявляються у застосуванні кластерів. Так, створюючи атмосферу ранкового міста в однойменній п'єсі, авторка передає світанковий серпанок регістровими тембровими зіставленнями, кластерами, густою педалізацією, а рух міста, що пробуджується після сну, - політональними поєднаннями мелодії і гармонії, поліритмічними візерунками.

Сьогодні продовжується тенденція, започаткована М. Скориком, а саме - зближення розважального і класичного мистецтва [6]. Сучасні композитори активно використовують джазову стилістику та естрадні ритми: "Регтайм", “Рок-н-рол” О. Личкіної, “Блюз”, “Джаз-вальс”, "Регтайм" (із сюїти “Граю джаз - 1") та “Балада", "Bossa nova" та "Бугі-вугі" (з сюїти "Граю джаз -2”) Г. Саська, “Джаз-вальс”, “Спогади” О. Нежигая. На прикладі п'єс “Ніжний смуток”, “Сум” (“Джазові та естрадні мініатюри”) Н. Лагодюк, написаних у стилі блюз, студенти знайомляться 3 його специфікою: “блюзовою сіткою”, альтерованою ладовістю, характерним ритмічним малюнком. П'єси розвивають навички виконання джазової музики, що полягають у “дихаючому” фразуванні, ритмічній організації акомпанементу та імпровізаційній свободі мелодики, відчутті колористики. У “Веселій трембіті” композиторка використовує музичну стилістику регтайму, поєднуючи її з інтонаціями українського фольклору (на це вказують гуцульський лад, коломийкові поспівки у мелодії). Мініатюра розвиває відчуття поліритмії, акордову техніку і техніку “стрибків”. Популярністю у репертуарі студентів-піаністів користується п’єса О. Личкіної “Ледачий Джо”, також написана в блюзовому стилі. Характер музики зазначений в авторській ремарці pigramente pezante (в перекл. 3 італ. - ліниво, важко). В уяві постає образ лінивого ковбоя, який не оминає нагоди подрімати - чи у затінку під деревом, чи в сідлі свого коня. Ритмічна вибагливість музики визначається постійним синкопуванням, несиметрична будова композиції створює відчуття імпровізаційності, невимушеності розвитку музичної думки, що підкреслює легковажний характер ковбоя.

Крім вищезгаданих п’єс, відчуття специфіки стилю, оволодіння своєрідними прийомами виконання джазових творів, пов'язаних із особливостями ритміки, інтонування та фразування, прищеплюють інші мініатюри Н. Лагодюк (із збірок “Веселий джаз”, “Школа джазового виконавства”, “Джазові етюди”, “Джазові хвилинки” тощо), композиції В. Журавицького, О. Науменка. Композитори ніби експериментують із композиційною технікою, міксуючи традиційну музичну лексику 3 джазовими метро-ритмічними прийомами та стилістичними елементами інших музичних культур.

Висновки 3 даного дослідження i перспективи подальшого розвитку у даному напрямку. Сучасна українська фортепіанна музика для дітей та юнацтва увібрала в себе творчі пошуки і розмаїття художніх принципів композиторів різних поколінь, відповідаючи своєму основному призначенню - педагогічному. Композитори здійснюють активні пошуки у сфері виразових, насамперед тембрових можливостей фортепіано, пріоритетними стають тембр та фонічне забарвлення, які значно еволюціонували, відтак звукопис став одним із елементів сучасної музичної лексики, а сонористика - активно задіяним видом композиторської техніки. У формуванні фактури творів це особливо позначилось на значенні педалізації, використанні широкого регістрового діапазону інструмента, застосуванні кластерів тощо. Для втілення образного змісту, який розвиває художню уяву, збуджує творчу фантазію, композитори ставлять перед виконавцем низку завдань. Дидактичне значення творів - розвинути піаністичні вміння $\epsilon$ визначальними як у легких мініатюрах, так і в п’єсах концертного плану. На прикладі творів студенти мають змогу познайомитись 3 широкою жанрово-образноюпалітрою, різними композиторськими техніками, творчою манероюавторів; опанувати такі форми розвивального навчання, як читка з листа та ескізне опрацювання навчального матеріалу. Крім того, у творах сучасних авторів робиться акцент на імпровізації як дієвому способі активізації художнього мислення, розвитку творчої ініціативи майбутніх музикантів-педагогів. Вищезазначені якості української фортепіанної музики для дітей та юнацтва сприяють їі успішному розвитку. Перспективу подальших наукових розвідок вбачаємо у висвітленні різних 
шляхів і форм, що сприятимуть не лише популяризації творів вітчизняних композиторів, а й 3 допомогою їх використання - підготовці музиканта-педагога, наділеного необхідними професійними компетентностями, щоб бути конкурентоспроможним на ринку праці.

\section{ЛІТЕРАТУРА}

1. Грінченко Т. Музично-педагогічна спадщина Едуарда Бриліна у вимірі потреб сучасної мистецької освіти. Наукові записки ВДПУ імені Михайла Коцюбинського. Серія: педагогіка $i$ психологія. 2020. Вип. 62. С. 187-192.

2. Данілішина М. Українська дитяча фортепіанна музика та її дидактично-виховні можливості. Актуальні питання мистецької педагогіки : зб. наук. праць ХГПА. Вип. 15. Хмельницький, 2016. C. $21-25$.

3. Козаренко О. Феномен української національної музичної мови. Львів : НТШ, 2000. 141 с.

4. Новосядла І. Цикли фортепіанних п’єс для дітей у творчості сучасних українських композиторів: художньо-образний аспект. Мистеитвознавчі записки: збірка наукових працьь. Вип. 18. Київ : Міленіум, 2010. С. 81-89.

5. Падалка Г. Педагогіка мистецтва (теорія і методика викладання мистецьких дисциплін). Київ: Освіта України, 2010. 274 с.

6. Простак Ю. Джаз и педагогіка. Мистецька освіта. Київ : ДАКККіМ, 2007. С. 98-99 .

7. Фрайт О. Фортепіанні альбоми та цикли українських композиторів для дітей: історія і сучасність. Дрогобич: Редакційно-видавничий відділ Дрогобицького державного педагогічного університету ім. І.Франка, 2010. 94 с.

8. Шульгіна В. Українська музична педагогіка. Київ: ДАКККіМ, 2005. 271 с.

\section{REFERENCES}

1. Hrinchenko, T. (2020). Muzychno-pedahohichna spadshchyna Eduarda Brylina u vymiri potreb suchasnoi mystetskoi osvity [Eduard Brylin's musical and pedagogical heritage in measuring of necessities of modern artistic education]. Scientific notes. Vinnytsia Mykhailo Kotsiubynsyi State Pedagogical University. Series: Pedagogy and Psychology. No.62. pp. 187-192. [in Ukrainian].

2. Danilishyna, M. (2016). Ukrainska dytiacha fortepianna muzyka ta yii dydaktychno-vykhovni mozhlyvosti [Ukrainian piano music for children and its didactic and educational opportunities]. Current issues of Art Pedagogy: collection of scientific works of Khmel'nytskyi Humanitarian and Pedagogical Academy. No.15. pp. 21 - 25. [in Ukrainian].

3. Kozarenko, O. (2000). Fenomen ukrainskoi natsionalnoi muzychnoi movy [The phenomen of the Ukrainian musical language]. L'viv: Shevchenko Scientific Society. 141 p. [in Ukrainian].

4. Novosiadla, I. (2010). Tsykly fortepiannykh pies dlia ditei u tvorchosti suchasnykh ukrainskykh kompozytoriv: khudozhno-obraznyi aspekt [Cycles of piano pieces in the contemporary Ukrainian composers' creativity: artistic aspect]. Art notes: collection of scientific works. Kyiv: Millenium. No. 18. pp. 81-89. [in Ukrainian].

5. Padalka, H. (2010). Pedahohika mystetstva (teoriia i metodyka vykladannia mystetskykh dystsyplin) [Art Pedagogics (the Theory and Methodic Art subjects teaching)]. Kyiv: Ukrainian Education. 274 p. [in Ukrainian].

6. Prostak, Yu. (2007). Dzhaz y pedahohika [Jazz and Pedagogy]. Art Education. Kyiv: National Academy of Culture and Arts management. pp. 98 99. [in Ukrainian].

7. Frait, O. (2010). Fortepianni albomy ta tsykly ukrainskykh kompozytoriv dlia ditei: istoriia $\mathrm{i}$ suchasnist [Ukrainian composers' piano albums and cycles for children: history and modernity]. Drogobych: editorial and publishing department of Drogobych Ivan Franko State Pedagogical University. 94 p. [in Ukrainian].

8. Shulgina, V. (2005). Ukrayinska muzychna pedahohika [Ukrainian music Pedagogy]. Kyiv, 271 p. [in Ukrainian].

Стаття надійшла до редакції 11.09.2020

\section{G58089}

"Музичне виховання - це не виховання музиканта, а насамперед виховання лғдини".

Василь Сухомлинсъкий український педагог, публіцист, письменник

“Все, що я хочу сқазати, сқазано в моїи музиці. Якщо мені захочеться додати ще щось, я напишу пісню”.

Tол Mаккартні

британський співак, қомпозитор

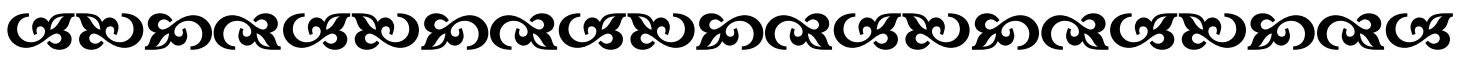

